Pierre-Yves Gueugniaud $\mathrm{MD}$,

Raoul Muchada MD,

Martine Moussa MD,

Dominique Haro $\mathrm{MD}$,

Paul Petit MD

\title{
Continuous oesophageal aortic blood flow echo-Doppler measure- ment during general anaesthesia in infants
}

Purpose: Invasive haemodynamic monitoring dunng general anaesthesia in infants is usually limited to very high nsk operations, such as cardiac surgery. Nevertheless, different surgical procedures and/or anaesthetic techniques justify additional monitoring for children, as for adults. The aim of this preliminary study was to evaluate the feasibility of using a new echo-Doppler device (Dynemo $3000 \AA$ ) capable of measuring continuous aortic blood flow during general anaesthesia in infants.

Methods: Aortic blood flow (ABF) was measured with a small cesophageal probe designed for newborns and infants. The aortic flowmeter was connected with satellite devices to visualise the haemodynamic profile which included ABF, pre-ejection period (PEPI), left ventricular ejection time (LVETi), mean arterial pressure, heart rate, stroke volume and systemic vascular resistance. Twelve infants, aged 8-26 mo, undergoing surgery under general anaesthesia were successively included in the evaluation of this device. Isoflurane ( $1 \%$ end-expired concentration) was introduced to maintain anaesthesia after induction with halothane, midazolam, fentanyl and atracurium.

Results: Correct positioning of the probe was easily obtained in all cases and the recording quality was excellent. whatever the operative position. Recordings of haemodynamic data showed some myocardial depression from isoflurane: decreased $A B F$ (indexed to body surface area) and lengthened PEP/LVET $\left(2.24 \pm 0.53 \mathrm{~L} \cdot \mathrm{min}^{1} \cdot \mathrm{m}^{2}\right.$ and 0.32 \pm 0.05 respectively, before introduction of isoflurane and $1.71 \pm 0.53 \mathrm{~L} \cdot \mathrm{min}^{1} \cdot \mathrm{m}^{2}(P=0.027)$ and $0.39 \pm 0.06(P$ $=0.007$ ) with isoflurane).

Conclusion: These preliminary results suggest that this continuous ABF echo-Doppler device may be valuable for peri anaesthetic monitoring in infants.

Objectif : La surveiliance per-anesthésique de la fonction cardiovasculaire par méthode invasive est exceptionnelle chez les nourrissons, et se limite généralement à des indications chirurgicales à très haut risque, telle que la chirurgie cardiaque. Pourtant, différentes situations per-opératoires et/ou anesthésiques justifieraient parfois une surveillance renforcée chez le nourrisson, comme chez l'adulte. Le but de cette étude préliminaire est d'évaluer la faisabilité d'une nouvelle méthode de mesure continue du débit aortique (DA) au cours de l'anesthésie générale des noumssons.

Méthodes : Un débitmètre aortique (Dynémo $3000 \AA$ ) permet grâce à une sonde oesophagienne pédiatrique écho-Doppler de petit calibre. de déterminer en continu le DA, le volume d'éjection systolique, les résistances vasculaires systémiques et les périodes de pré-éjection (PEPI) et d'éjection du ventricule gauche (LVETi). Douze enfants, de 8 à 26 mois, subissant une intervention chirurgicale sous anesthésie générale ont été successivement inclus. L'induction anesthésique a été réalisée par halothane, midazolam, fentanyl et atracunum et l'entretien par isoflurane (fraction téléexpiratoire $=1 \%$ ).

Résultats : La mise en place de la sonde oesophagienne écho-Doppler a été aisée dans tous les cas. Les enregistrements simultanés du diamètre et du flux aortiques ont été d'excellente qualité, quelle que soit la position opératoire. L'enregistrement des données hémodynamiques montre un effet dépresseur myocardique de lisoflurane : baisse significative du DA (indexé à la surface corporelle) et allongement du rapport PEP/VET $(2.24 \pm 0.53$ $L \cdot \min { }^{1} \cdot \mathrm{m}^{-2}$ et $0.32 \pm 0.05$, respectivement avant l'introduction de l'isolurane et $1.71 \pm 0.53 \mathrm{~L} \cdot \mathrm{min}{ }^{1} \cdot \mathrm{m}^{2}(P=$ 0.027 ) et $0.39 \pm 0.06(P=0.007)$ sous isoflurane).

Conclusion : Ces résultats préliminaires suggèrent que l'enregistrement continu du DA par voie oesophagienne peut être précieux pour renforcer la surveillance per-anesthésique des nournssons.

From the Department of Anacsthesiology, Edouard Herriot Hospital and Claude Bernard University, Lyon, France.

Address correspondence to: Dr. P.Y. Gueugniaud, SAR VII (Pavillon I), Hôpital Edouard Herriot, Place d'Arsonval, 69437 Lyon Cedex 03, France. Accepted for publication April 13, 1997. 
I

NVASIVE haemodynamic monitoring during general anaesthesia in infants is usually limited to high risk surgery. ${ }^{1}$ Moreover, transoesophageal echocardiography is not yet readily available for infants and other techniques such as $\mathrm{CO}_{2}$-rebreathing are still proposed. These reasons encouraged the development of non-invasive ultrasonic techniques to measure cardiac output in newborns and infants. Initially, blood flow velocity was measured using a Doppler suprasternal transducer. ${ }^{2-4}$ The difficulty in keeping the transducers in precise, fixed positions makes it difficult to use them for continuous monitoring in clinical practice. The oesophageal route was first used in an attempt to overcome this difficulty. ${ }^{5}$ A probe that could be oriented from outside when inserted into the oesophagus was suggested in 1978. In the mid 1980s, an oesophageal probe with greater operating simplicity was developed by INSERM (U281) in France. ${ }^{6-7}$ Application of this methodology in adults during general anaesthesia for surgery or in intensive care patients revealed the clinical usefulness of aortic blood flow measurement ${ }^{8-12}$ Today, non-invasive haemodynamic monitoring can be performed with an echo-Doppler aortic blood flowmeter (Dynemo 3000® Sometec Inc, France). In children, use of the oesophageal route required development of a miniaturized probe that could be oriented from outside and yet that was sufficiently flexible to be safe when used in infants. This probe has been developed, following the same method to continuously measure descending thoracic aortic diameter and blood velocity simultaneously in infants as in adults. The aim of this preliminary study was to evaluate the feasibility of use of this recently developed new device, for continuous measurement of aortic blood flow (ABF) during general anaesthesia in infants.

\section{Methods}

Measurement principle

Velocity is measured using the Doppler formula:

$$
v=\frac{\mathrm{C} \times \Delta \mathrm{F}}{2 \mathrm{Fe} \times \cos \Phi} \text {, where } \mathrm{C}=\text { Ultrasound velocity }
$$

ultrasound inside the blood, $\Delta \mathrm{F}=$ Frequency variation of emitted ultrasound, $\mathrm{Fe}=$ Emission frequency, $\boldsymbol{\Phi}=$ Angle of incidence and reflection of ultrasound against the red cells. Determination of $\mathrm{ABF}$ requires simultaneous and continuous measurement of the aorta section and of the blood velocity inside the aorta, at the same anatomical level where the aorta and the oesophagus are nearly parallel. Using the specially designed ultrasonic paediatric probe introduced into the oesophagus, we measured the diameter of the descending thoracic aorta with an $\mathrm{M}$ mode echographic system and blood flow velocity with a pulsed Doppler velocimeter. (Figure 1)

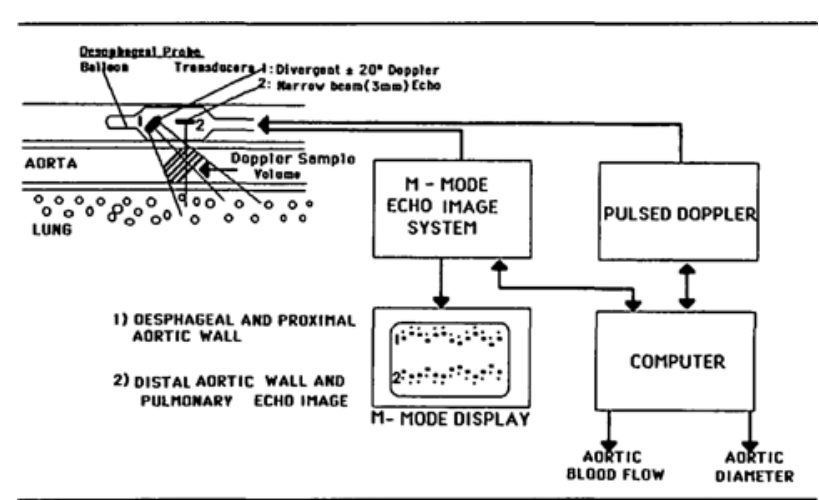

FIGURE 1 Principle of aortic blood flow measurement. Aortic diameter is measured using $\mathrm{M}$-mode imaging system and blood flow velocity is measured using pulsed Doppler velocimeter.

\section{Probe and flowmeter}

The paediatric oesophageal probe has two ultrasound transducers $(3 \times 3 \mathrm{~mm})$, located at the distal part of the probe. The first operates at $10 \mathrm{MHz}$ M-echo mode scanner, perpendicular to the centerline. The second is a Doppler pulsed emission transducer operating at $5 \mathrm{MHz}$ and mounted at an angle of 600 to the centre line of the probe: the pulsed Doppler is emitted with a $20^{\circ}$ divergent beam and the gate Doppler signal depth is automatically adapted to the aortic diameter value. This small probe, specially designed for newborns and infants, measures $4.5 \mathrm{~mm}$ in external diameter and is $40 \mathrm{~cm}$ long. For infants, a $12 \mathrm{~mm}$ diameter cylindrical latex balloon is mounted on the sheath ready to be filled with $2.5 \mathrm{ml}$ water. This inflated balloon which surrounds the transducers maintains a constant angle of incidence of the ultrasound beams and allows the captors to rotate freely inside it without contact against the oesophageal mucosal wall. The balloon ensures transmission of ultrasound waves without air interposition and dissipates any heat produced. The $10 \mathrm{MHz} \mathrm{M}$-mode scan and the $5 \mathrm{MHz}$ pulsed Doppler system make it possible to obtain a very clear image resolution. Both parameters are simultaneously and continuously recorded at the same anatomical level. The oesophageal probe was inserted and positioned immediately after induction of anaesthesia and before the introduction of isoflurane. The depth of introduction of the probe into the oesophagus varied according to the height of the infant and was measured between the echo transducer placed on the third intercostal juxtasternal space and a slide rubber ring placed at the level of the mouth (or the nose). This distance approximated the level where the aorta and the oesophagus are parallel. 
The flowmeter includes three main parts: $M$-mode imaging system for diameter measurement, pulsed Doppler for velocity measurement, and a microprocessor system controlling flowmeter functions, and peripheral monitoring devices. An oscillometric tensiometer provides mean arterial pressure (MAP) values. An electrocardioscope collects the ECG signal and calculates the heart rate (HR) (Propaq 104 ELB, Protocol, USA).

The haemodynamic profile integrates $A B F, M A P$, $\mathrm{HR}$ and calculates stroke volume (obtained from the formula: $\mathrm{SV}(\mathrm{ml})=\mathrm{ABF} / \mathrm{HR})$ and systemic vascular resistance (calculated from the formula: SVR $\left(\right.$ dyn $\left.\cdot \mathrm{sec} \cdot \mathrm{cm}^{-5}\right)=\mathrm{MAP} / \mathrm{ABF} \times 79.9$, whenever a new arterial pressure is provided). These two parameters are indexed to ABF. Moreover, systolic time intervals (STI) are measured from computerized analysis of the ECG signal ( $Q$ wave detection) and the acceleration signal which is derived from the Doppler velocity signal. Opening and closing of the aortic valve are detected on the computered analysis of the acceleration signal. The computer determines the length of the pre-ejection period (PEP) between the $Q$ wave and the beginning of the systolic acceleration front, corresponding to the aortic valve opening.

Starting at the end of PEP, measurement of the left ventricular ejection time (LVET) is obtained by searching in the acceleration signal the second maximum of systolic deceleration corresponding to the aortic valve closure. ${ }^{13}$ The PEP and LVET are automatically and continuously measured and indexed to $\mathrm{HR}$ according to Weissler's formula. ${ }^{14}$ The PEP/LVET ratio is also calculated automatically. These values are presented in table form and updated every eight seconds on a screen display. (Figure 2) Finally, the haemodynamic profile is recorded every two minutes (or at the operator's request) on soft magnetic support.

\section{Patients and anaesthesia}

With the approval of the Ethics Committee at our institution, and after obtaining informed consent from parents, 12 infants with a body weight from 5 to 15 $\mathrm{kg}$ undergoing general anaesthesia for peripheral surgery were successively enrolled in the study.

After premedication with hydroxyzine, general anaesthesia was first induced with halothane $(3 \%-2 \%)$ then by $0.1 \mathrm{mg} \cdot \mathrm{kg}^{-1}$ midazolam, $10 \mu \mathrm{g} \cdot \mathrm{kg}^{-1}$ fentanyl and neuromuscular blockade was procured with 0.5 $\mathrm{mg} \cdot \mathrm{kg}^{-1}$ atracurium. After nasotracheal intubation, general anaesthesia was maintained with nitrous oxide $(50 \%)$ and isoflurane introduced five minutes after induction. Isoflurane concentrations were then adapted to obtain $1 \%$ end-expired concentration.

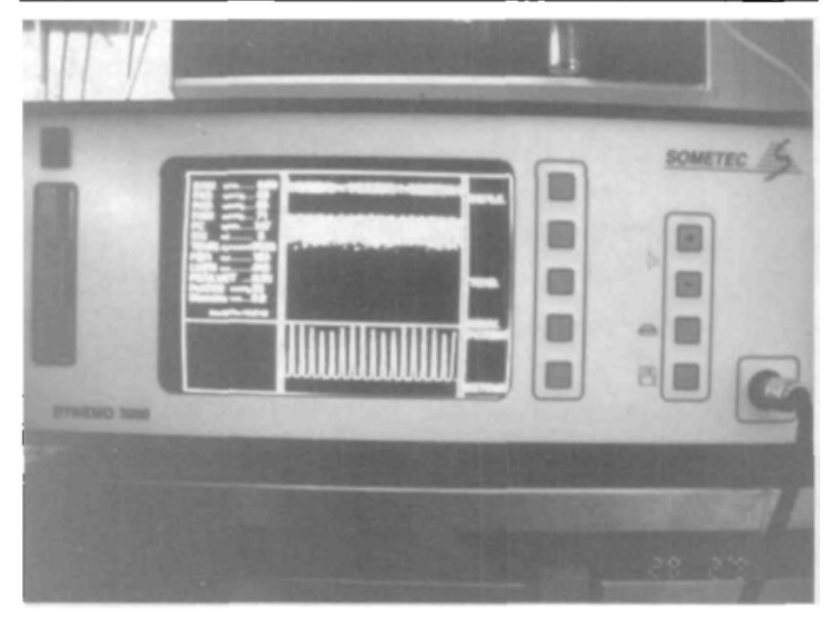

FIGURE 2 The Dynemo 30000 device. On the upper part of the screen, the $\mathrm{M}$-mode echo of the aortic walls; on the lower part, the Doppler flow velocity. On the left part of the screen, the hacmodynamic data shown in table form (updated every $8 \mathrm{sec}$ ).

\section{Measurements of the study}

When the recorded $\mathrm{ABF}$ was satisfactory (stable and clear images of aortic walls and Doppler velocity signal on the screen for more than one minute), initial data, before the introduction of isoflurane, were collected simultaneously with the last arterial pressure values and calculated SVR $\left(t_{1}\right)$. Then, a second set of haemodynamic measurements was collected using the same criteria, three minutes after end-expired concentration of isoflurane reached $1 \%\left(t_{2}\right)$. As the expected duration of anaesthesia was short and as the second part of the anaesthetic was given to facilitate application of wound dressings, the oesophageal probe was removed before these manipulations were accomplished.

Results are reported as mean $\pm \mathrm{SD}$. Data were compared between $t_{1}$ and $t_{2}$ using a paired Student's $t$ test. Differences were considered to be statistically significant at the $5 \%$ critical level.

\section{Results}

Twelve infants successively included in the study underwent superficial surgery under general anaesthesia in our reconstructive and plastic surgery unit (skin grafts, wound excisions or minor orthopaedic procedures) : mean age was $16 \pm 7$ months, mean weights were $10.1 \pm 2.2 \mathrm{Kg}$, and mean body surface area was $0.45 \pm 0.08 \mathrm{~m}^{2}$. The mean duration of anaesthetic was $47 \pm 14 \mathrm{~min}$.

No untoward incidents were noted using the device. Aortic diameter and ABF measurements were 
easily obtained in all cases. The recording quality was excellent whatever the operative position (supine or lateral positions for three patients).

Table I shows the haemodynamic variations initially induced by the inhalation of isoflurane: $A B F, S V$ and SVR are indexed to body surface area (ABFI, SVI and SVRI). The ABFI and LVETi decreased $(P=0.027$, and $P=0.007$, respectively) and the PEP/LVET ratio increased $(P=0.007)$ during the introduction of isoflurane. Simultaneously MAP, SVI and $\mathrm{P}_{\mathrm{ET}} \mathrm{CO}_{2}$ decreased while SVRI and PEPi increased numerically but without statistical significance ( $P$. NS).

\section{Discussion}

Although it has been argued that invasive measurement of cardiac output allows earlier interventions in seriously ill patients or during critical surgical procedures (sepsis, major trauma, myocarditis, low cardiac output state post bypass, and whenever catecholamines could be useful), the practical problem of inserting balloon catheters into small children are such that many paediatric units rely solely on heart rate, blood pressure, pulse oximetry and $\mathrm{P}_{\mathrm{ET}} \mathrm{CO}_{2}$ to monitor cardiovascular responses. Unfortunately, clinical assessment of cardiac function using these measurements has been shown to be unreliable in children ${ }^{15}$ (as in adults). ${ }^{11}$ There is, therefore, a need in paediatric critical care, as during paediatric anaesthesia, for an easy, accurate, non-invasive measure of blood flow. Nevertheless, transoesophageal echocardiography (TEE) is not easily available everywhere for small infants. ${ }^{16,17}$ Also, the cardiovascular approach provided by TEE is only discontinuous and partly operator-dependent. Blood flow measurement using ultrasound techniques represents another possible approach applicable during general anaesthesia ${ }^{18}$ and allowing acceptable agreement and precision with the direct Fick method. ${ }^{19}$
We have previously shown that this non-invasive method correlated satisfactorily with electromagnetic flow in animals 20,21 and with thermodilution in humans. ${ }^{7-9}$ The device allows measurement of the aortic diameter and velocity at the same anatomical level continuously and non-invasively. The importance of this simultaneous measurement has been previously outlined in adults ${ }^{22}$ and children. ${ }^{23}$ The haemodynamic profile integrates ABF, MAP, HR and calculates SV and SVR. The PEPi and LVETi are also measured automatically, as previously described, ${ }^{13}$ allowing another approach to the estimation of myocardial contractility. ${ }^{24}$

The transoesophageal Doppler-echographic technique for continuous measurement of $A B F$ in descending aorta associated with $\mathrm{P}_{\mathrm{ET}} \mathrm{CO}_{2}$ monitoring allows early detection of alterations in tissue (or pulmonary) perfusion. ${ }^{10}$ The clinical usefulness of this non-invasive haemodynamic profile has been reported in various anaesthetic situations: during vascular surgery, ${ }^{25,26}$ during orthopaedic surgery under tourniquet, ${ }^{27}$ during laparoscopy, ${ }^{8,28}$ and for rapid detection of acute left ventricular failure. ${ }^{12,29}$ Until recently, this monitoring technique was not available for use in infants. Although different ultrasonic approaches had already been tested (transtracheal Doppler, ${ }^{30,31}$ ascending $^{32,33}$ or descending ${ }^{34} \mathrm{ABF}$ ), none of these techniques could be used for continuous management during routine anaesthesia for infants. The recent availability (1996) of a paediatric oesophageal probe has changed how infants may be monitored.

This preliminary clinical study has allowed us to evaluate the feasibility of this device. The echographic image of aortic walls and the Doppler flow could be recorded easily without delay. The haemodynamic data appeared reliable in all cases and similar trends for each infant during isoflurane anaesthesia were identi-

TABLE I Hacmodynamic variations induced by the introduction of isoflurane

\begin{tabular}{|c|c|c|c|}
\hline Measurement & Before isoflurane $\left(t_{1}\right)$ & $\begin{array}{l}\text { After } 3 \text { min } \\
1 \% \text { isoflurane }\left(t_{2}\right)\end{array}$ & $P$ \\
\hline $\mathrm{HR}\left(\mathrm{b} \cdot \mathrm{min}^{-1}\right)$ & $140 \pm 18$ & $136 \pm 18$ & NS \\
\hline $\mathrm{MAP}(\mathrm{mm} \mathrm{Hg})$ & $73.2 \pm 19.2$ & $68.8 \pm 15.1$ & NS \\
\hline ABFI $\left(\mathrm{L} \cdot \mathrm{min}^{-1} \cdot \mathrm{m}^{-2}\right)$ & $2.24 \pm 0.53$ & $1.71 \pm 0.53$ & 0.027 \\
\hline $\mathrm{PEPi}(\mathrm{msec})$ & $142 \pm 22$ & $158 \pm 19$ & NS \\
\hline LVETi (msec) & $443 \pm 23$ & $406 \pm 34$ & 0.007 \\
\hline PEP/LVET & $0.32 \pm 0.05$ & $0.39 \pm 0.06$ & 0.007 \\
\hline SVI $\left(\mathrm{ml} \cdot \mathrm{m}^{-2}\right)$ & $16 \pm 4$ & $12.6 \pm 6$ & NS \\
\hline SVRI (dyn.sec $\cdot \mathrm{cm}^{-5} \cdot \mathrm{m}^{2}$ ) & $2809 \pm 960$ & $3749 \pm 2595$ & NS \\
\hline $\mathrm{P}_{\mathrm{ET}} \mathrm{CO}_{2}(\mathrm{~mm} \mathrm{Hg})$ & $37.7 \pm 5.1$ & $35.8 \pm 4.5$ & NS \\
\hline
\end{tabular}

Data are expressed as mean $\pm \mathrm{SD}$.

$\mathrm{HR}=$ heart rate $; \mathrm{MAP}=$ mean arterial pressure; $\mathrm{ABFI}=$ aortic blood flow indexed to $\mathrm{BSA}$; PEPi = pre-ejection period indexed to $\mathrm{HR}$; LVETi = left ventricular ejection time indexed to $\mathrm{HR} ; \mathrm{SVI}=$ stroke volume indexed to BSA; SVRI = systemic vascular resistance indexed to $\mathrm{BSA} ; \mathrm{P}_{\mathrm{ET}} \mathrm{CO}_{2}=$ End-tidal carbon dioxide pressure; $\mathrm{BSA}=$ body surface area; $\mathrm{NS}=$ not significant. 
fied: ABFI and LVETi decreased whereas PEP/LVET ratio increased during isoflurane introduction. On the other hand, the decreases in MAP, SVI and $\mathrm{P}_{\mathrm{ET}} \mathrm{CO}_{2}$ and increases in SVRI, PEPi were without statistical significance. The results suggest that isoflurane initially decreases myocardial contractility. The variations in STI are the reflection of the inotropic parameters: PEP reflects the isometric phase and LVET the isotonic phase of the left ventricular contraction. A simplified expression of alterations in STI is provided by the ratio of PEP/LVET: among normal persons this ratio averages $0.35 \pm 0.04$. In adults, increases in PEP/LVET to 0.44 denote diminished left ventricular performance. ${ }^{35}$ The increase in PEP/LVET ratio associated with the decrease of ABFI confirms some decrease in left ventricular contractility. ${ }^{24}$

Mean arterial pressure and $\mathrm{P}_{\mathrm{ET}} \mathrm{CO}_{2}$ also decreased but not significantly. The slight decrease in $\mathrm{P}_{\mathrm{ET}} \mathrm{CO}_{2}$ associated with the decrease in cardiac output when the ventilation and the metabolic state are stable indicate a moderate alteration in tissue perfusion..$^{28,36}$ In healthy infants undergoing anaesthesia with isoflurane at low concentrations, the decreased myocardial contractility is probably compensated for by improved systemic vascular resistance to normalize arterial pressure, and without clinical consequences.

Finally, our findings confirm that the standard monitors used during general anaesthesia in infants may not be reliable with respect to detection of minor myocardial disturbances. ${ }^{37}$ If these preliminary results are repeated in future studies, then this method of continuous ABF echo-Doppler measurement could be a useful addition to peri-anaesthetic monitoring techniques in infants.

\section{Acknowledgments}

The authors wish to thank Dr. J.M. Davies for her valuable revision of the paper.

\section{References}

1 Damen J, Wever JEAT. The use of balloon-tipped pulmonary artery catheters in children undergoing cardiac surgery. Intensive Care Med 1987; 13: 266-72.

2 Alverson DC, Eldridge M, Dillon T, Yabek SM, Berman $W J r$. Noninvasive pulsed Doppler determination of cardiac output in neonates and children. J Pediatr 1982; 101: 46-50.

3 Walther FJ, Siassi B, Ramadan NA, Ananda AK, Wu $P Y K$. Pulsed Doppler determinations of cardiac output in neonates: normal standards for clinical use. Pediatrics 1985; 76: 829-33.

4 Payen D, Ecoffey C, Carli P, Dubousset A-M. Pulsed Doppler ascending aorta, carotid, brachial, and femoral artery blood flows during caudal anesthesia in infants. Anesthesiology 1987; 67: 681-5.

5 Daigle RE, Miller CW, Histand MB, McLeod FD, Hokanson DE. Nontraumatic aortic blood flow sensing by use of an ultrasonic esophageal probe. J Appl Physiol 1975; 38: 1153-60.

6 Cathignol D, Fourcade C. Sonde intracorporelle ultrasonore. Brevet INSERM no 78-14494.

7 Lavandier B, Cathignol D, Muchada R, Bui Xuan B, Motin J. Noninvasive aortic blood flow measurement using an intraesophageal probe. Ultrasound Med Biol 1985; 11: 451-60.

8 Muchada $R$, Lavandier $B$, Catbignol $D$, et al. Non invasive haemodynamic monitoring in gynaecological laparoscopy. (French) Ann Fr Anesth Reanim 1986; 5: 14-7.

9 Muchada $R$, Catbignol $D$, Lavandier $B$, Lamazou J, Haro $D$. Aortic blood flow measurement. American Journal of Noninvasive Cardiology 1988; 2: 24-31.

10 Muchada $R$, Cathignol D. Esophageal measurment of aortic blood flow by echo-Doppler. In: Vincent JL (Ed.). Update in Intensive Care and Emergency Medicine. Berlin: Springer Verlag, 1987: 356-65.

11 Gueugniaud PY, Caritat R, Barreiro G, Muchada $R$, Bertin-Maghit $M$, Petit $P$. Noninvasive haemodynamic monitoring for burnt patients: feasibility and usefulness of aortic blood flow measurement. (French) Réanimation Urgences 1993; 2: 533-8.

12 Gueugniaud PY, Muchada R, Bertin-Maghit M, Griffith $N$, Petit $P$. Non invasive continuous haemodynamic and $\mathrm{P}_{\mathrm{ET}} \mathrm{CO}_{2}$ monitoring during peroperative cardiac arrest. Can J Anaesth 1995; 42: 910-3.

13 Muchada R, Vernier F, Fady J-F, Haro D, Lavandier B, Cathignol $D$. A new automatic measurement method of systolic time intervals (STI). J Cardiothorac Vasc Anesth 1992; 6 (Suppl 1): 22.

14 Weissler AM, Harris WS Schoenfeld CD. Systolic time intervals in heart failure in man. Circulation 1968; 37: 149-56.

15 Wolf WJ, Neal MB, Peterson MD. The hemodynamic and cardiovascular effects of isoflurane and halothane anesthesia in children. Anesthesiology 1986; 64: 328-33.

16 Gentles $T L$, Rosenfeld HM, Sanders SP, Laussen PC, Burke $R P$, van der Velde $M E$. Pediatric biplane transesophageal echocardiography: preliminary experience. Am Heart J 1994; 128: 1225-33.

17 Lam J, Neirotti RA, Cubbers WJ, et al. Usefulness of biplane transoesophageal echocardiography in neonates, infants and children with congenital heart disease. Am J Cardiol 1993; 72: 699-706.

18 Mark JB, Steinbrook RA, Gugino LD, et al. Continuous noninvasive monitoring of cardiac output with 
esophageal Doppler ultrasound during cardiac surgery. Anesth Analg 1986; 65: 1013-20.

19 Espersen $K$, Jensen $E W$, Rosenborg $D$, et al. Comparison of cardiac output measurement techniques: thermodilution, Doppler, $\mathrm{CO}_{2}$-rebreathing and the direct Fick method. Acta Anaesthesiol Scand 1995; 39: 245-51.

20 Lavandier B, Muchada R, Chignier E, Fady JF, Birer A, Cathignol $D$. Assessment of a potentially noninvasive method for monitoring aortic blood flow in children. Ultrasound Med Biol 1991; 17: 107-16.

21 Muchada $R$, Rinaldi $A$, Catbignol $D$. Non invasive cardiovascular monitoring during general anaesthesia. (Italian) Minerva Anestesiol 1990; 56: 199-205.

22 Muchada $R$, Cathignol D. Fontaine B, Lavandier $B$. Will morphometric data permit the determination of thoracic aorta caliber for precise measurement of blood flow in adults? (French) JEMU 1990; 11: 76-80.

23 Muchada $R$, Rinaldi $A$, Lavandier $B$, Cathignol $D$. Transesophageal Doppler ultrasound in children: importance of aortic diameter evaluation audits changes for the evaluation of aortic output. (Italian) Minerva Anestesiol 1992; 58: 347-53.

24 Boudoulas $H$. Systolic time intervals. Eur Heart J 1990; 11(Suppl 1): 93-104.

25 Brunel D, Muchada R. Evaluation of tissue perfusion by simultaneous monitoring of aortic flow rate and capnography. (French) Presse Med 1991; 20: 1665-6.

26 Gueugniaud PY, Tournadre JP, Muchada R, BertinMaghit $M$, Petit $P$. Intérêt de la perfusion de dobutamine pour traiter la dépression myocardique sous anesthésie générale diagnostiquée par la surveillance hémodynamique non invasive. Ann Fr Anesth Réanim 1995; 14: R32.

27 Tournadre JP, Moulaire V, Barreiro G, Brunel D, Van Straten V, Mucbada R. Simultaneous monitoring of noninvasive hemodynamic profile and capnography for tissue perfusion evaluation. J Anesth 1994; 8: 400-5.

28 Muchada $R$, Rinaldi $A$. Haemodynamic and $\mathrm{P}_{\mathrm{ET}} \mathrm{CO}_{2}$ variations during laparoscopic cholecystectomy. In : Gullo A (Ed.). Anaesthesia, Pain, Intensive Care and Emergency medicine (APICE). Trieste: Fogliazza, 1994: 539-54.

29 Gueugniaud PY, Bertin-Maghit M, Petit P, Muchada $R$. Diagnosis of circulatory arrest from carbon dioxide embolism with aortic blood flow and capnogram monitoring during laparoscopic cholecystectomy. (French) Ann Fr Anesth Réanim 1995; 14: 417-20.

30 Abrams JH, Weber RE, Holmen KD. Continuous cardiac output determination using transtracheal Doppler: initial results in humans. Anesthesiology 1989; 71: 11-5.

31 Peterson RJ, Kissoon N, Bayne EJ, Marvin WJ Jr, Murphy SP, Ceithaml EL. Transtracheal Doppler in infants and small children following surgery for congenital heart disease : rational use of an improved technology. Crit Care Med 1994; 22: 1294-300.

32 Trang TTH, Tibballs J, Mercier J-C, Beaufils $F$. Optimization of oxygen transport in mechanically ventilated newborns using oximetry and pulsed Dopplerderived cardiac output. Crit Care Med 1988; 16: 1094-7.

33 Seear MD, D'Orsogna L, Sandor GGS, De Souza E, Popov R. Doppler-derived mean aortic flow velocity in children: an alternative to cardiac index. Pediatr Cardiol 1991; 12: 197-200.

34 Seear $M$, Webber S, Leblanc J. Descending aortic blood flow velocity as a noninvasive measure of cardiac output in children. Pediatr Cardiol 1994; 15: 178-83.

35 Weissler AM. Current concepts in cardiology. Systolictime intervals. N Engl J Med 1977; 296: 321-4.

36 Piriou V, Muchada R, Tournadre JP. End tidal $\mathrm{CO}_{2}$ et débit aortique. Ann Fr Anesth Réanim 1995; 14: R31

37 Gueugniaud PY, Muchada $R$, Moussa $M$, Petit $P$. Noninvasive hemodynamic monitoring during general anesthesia in infants: interest of a continuous aortic blood flow echo-Doppler measurement. Anesthesiology 1995; 83: Al160. 